\title{
A possible source of raw material for ceramics from the area of the towns Yambol and Elhovo - preliminary results
}

\section{Възможен източник на суровината за керамика от района на Ямбол и Елхово - предварителни резултати}

\author{
Tanya Stoylkova, Kristina Kostova, Philip Machev \\ Таня Стоилкова, Кристина Костова, Филип Мачев
}

Sofia University St. Kliment Ohridski, Faculty of Geology and Geography, 1504 Sofia; E-mail: tstoilkova@gea.uni-sofia.bg

\begin{abstract}
The application of geological methods of investigation to archeological objects gives the necessary information about the source of materials (rocks, clays, etc.) for preparation of different tools during the Prehistoric time. Using XRF analyses of clays from natural outcrops along the valley of the Tundzha River and of ceramic vessels from the area of the towns of Yambol and Elhovo we found out that these vessels were prepared from clays from this region.
\end{abstract}

Keywords: ceramic, clays, geochemical characteristic.

\section{Introduction}

One of the most important problems to solve during investigations of archeological objects is the determination of the source of the raw material (clays for ceramic dishes, ores for metallurgic finds or stones for stone tools). Sometimes the solving of this task is not successful. There are many examples that it is impossible to find the source area (Machev et al., 1998) and this is a big challenge for a researcher. For answering this question we compare ceramic fragments from the area of the towns of Yambol and Elhovo with clays from different deposits located along the valley of the Tundzha River, using $\mathrm{X}$-ray fluorescence analyses (XRF) and geochemical investigations. This method allows obtaining information about the content of main petrogenic components. Comparison of both groups (clays and fragments) after these criteria gives reliable information for conclusions.

\section{Samples description}

The samples from ceramic vessels were collected by drilling because they have been restored or they are whole vessels. They were found during the excavations of necropolises along the valley of the
Tundzha River. Their age is around 3th-2nd millenary BC. More detailed commentary on the dating, context, and cultural affiliation of the artifacts is another research, and it cannot be discussed here. The investigated vessels are represented by jugs, cups, bowls, cantaros (Fig. 1A).

\section{Composition of the clays}

The clay samples (29 samples) were collected from local deposits close to the river valley or from the outcrops of the Neogene Elhovo Formation (Dabovski et al., 1989). Six samples are from shallow boreholes. The last samples and these from the stratified formation were collected close to the river valley, too. The clays differ in color - gray, white-gray, brownish. They always contain various amount of psamitic particles so some of them can be classified as sandy clays. The samples from local outcrops of possible Quaternary age are richer in sand material.

The amount of $\mathrm{SiO}_{2}$ in the clays varies widely from 58.06 to $78.06 \%$. The same behavior has $\mathrm{Al}_{2} \mathrm{O}_{3}$ with variations in the range $12.65-26.07 \%$. The clays are depleted on $\mathrm{K}_{2} \mathrm{O}+\mathrm{Na}_{2} \mathrm{O}(1.2-6.4 \%)$. Seven samples have high $\mathrm{CaO}$ content (up to $35.53 \%$ ) and 


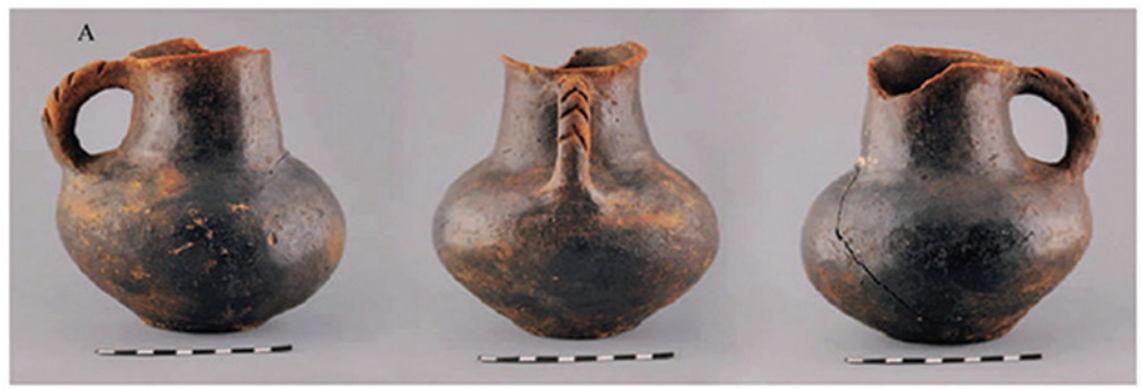

B

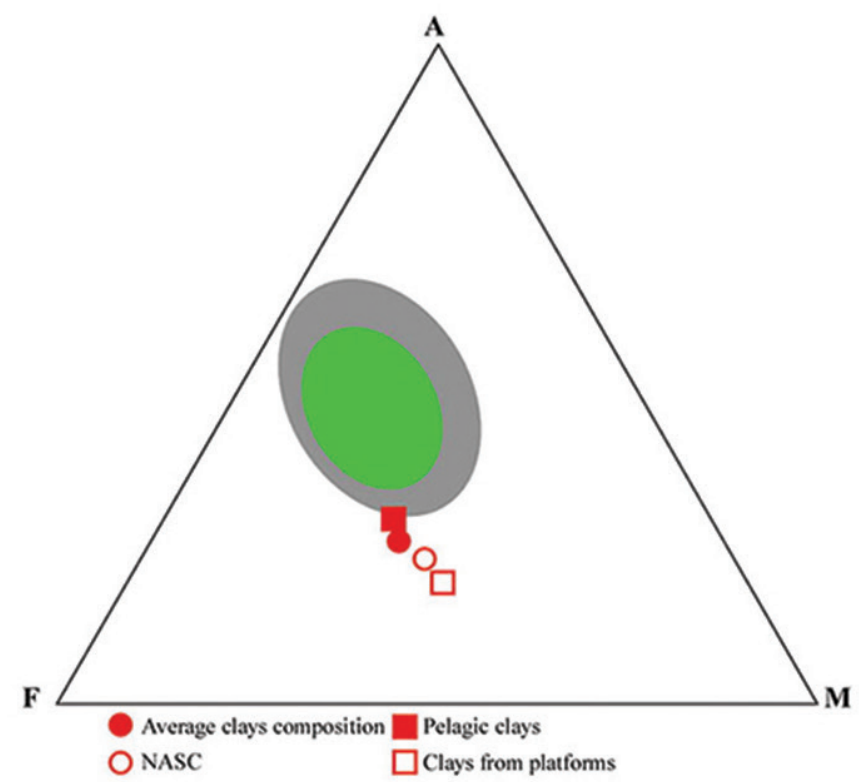

Fig. 1. $A$, ceramic jug from Lozanska Mogila investigated in this study; $B$, AFM diagram for investigated clays (gray field) and ceramic fragments (green field). Data for clays - NASC, pelagic or clays from platforms, after Carmichael (1989).

LOI more that $30 \%$ as a result of a presence of calcite in them. Very often such $\mathrm{CaO}$ rich clays were formed by weathering of marls. These samples were excluded from interpretation because no ceramic fragments with high $\mathrm{CaO}$ content were found. This allows us to conclude that this type of clays was not used for ceramic production. Probably the mechanical properties of $\mathrm{CaO}$ rich clays are inappropriate for ceramic production.

On AFM diagram $\left(\mathrm{A}=\mathrm{Al}_{2} \mathrm{O}_{3}-3 \mathrm{~K}_{2} \mathrm{O} ; \mathrm{F}=\mathrm{FeO}\right.$; $\mathrm{M}=\mathrm{MgO}$ in molecular weight) the clays form elongated field near to the A-F line as a result of the low $\mathrm{MgO}$ content in them (Fig. 1B). The investigated clays differ in composition from the clays used as standards - NASC, pelagic or clays from platforms. On the Harker type diagrams $\mathrm{Al}_{2} \mathrm{O}_{3}, \mathrm{FeO}$ and $\mathrm{MgO}$ decreases with $\mathrm{SiO}_{2}$ increasing. Only $\mathrm{K}_{2} \mathrm{O}$ and $\mathrm{Na}_{2} \mathrm{O}$ have positive correlation with $\mathrm{SiO}_{2}$.

\section{Composition of the vessels}

The $\mathrm{SiO}_{2}$ content varies in the range $53.02-70.25 \%$ that is more limited compared to the clays from lo- cal deposits. $\mathrm{Al}_{2} \mathrm{O}_{3}(15.21-18.41 \%)$ varies in narrow range and the $\mathrm{K}_{2} \mathrm{O}+\mathrm{Na}_{2} \mathrm{O}$ sum is higher as in the clays. On the Harker type diagrams vs $\mathrm{SiO}_{2}$ positive correlation with $\mathrm{K}_{2} \mathrm{O}$ and $\mathrm{Na}_{2} \mathrm{O}$ and negative with $\mathrm{Al}_{2} \mathrm{O}_{3}, \mathrm{FeO}$ and $\mathrm{MgO}$ is observed. On the AFM diagram the field of ceramic vessels covers the field of the clays, but it is more compact due to the narrow variations in the content of the main petrogenic elements.

\section{Conclusions}

When comparing the chemical composition of the possible source clays with ceramics we must take into account that the added "improved" material can influence and change it in the ceramics. Most often, this material represents small pieces from broken rocks or sand from neighbour river. Nevertheless the chemical composition of the ceramic provides reliable information for answering the question about the source of the row material for ceramic production. In our case, we have no information about the type of the added material, 
because the samples are from whole ceramic vessels. Probably due to the presence of added material the $\mathrm{K}_{2} \mathrm{O}$ and $\mathrm{Na}_{2} \mathrm{O}$ content in ceramics is higher

The geochemical investigations of the clays from the area of the valley of the Tundzha River and ceramic vessels from the area of Yambol and Elhovo towns show clearly expressed similarities (part of them shown on Fig. 1). This allows us to conclude that the source raw material for ceramic production is the clays cropping up the valley of the Tundzha River. Therefore, it is difficult to accept the possibility of importing raw materials.
Acknowledgments: The investigations were financially supported by the National Fund of Scientific Research, Grant № 10/8-2016.

\section{References}

Carmichael, R. S. 1989. Practical Handbook of Physical Properties of Rocks and Minerals. CRC Press, Boca Raton, 756 p.

Dabovski, Ch., S. Savov, G. Chatalov, G. Shilyafov. 1989. Explanatory Notes to the Geological Map of Bulgaria on Scale 1:100 000, Elhovo Map Sheet. Committee of Geology and Mineral Resources, Geology and Geophysics Ltd. 76 p. (in Bulgarian).

Machev, Ph., H.-J. Bautsch, A. Rusinova. 1998. Blue schists from archeological find. - J. Geol. Mineral. Res., 4, 31-34 (in Bulgarian with English abstract). 